\title{
Banff Renal Quantitative Criteria Score
}

National Cancer Institute

\section{Source}

National Cancer Institute. Banff Renal Quantitative Criteria Score. NCI Thesaurus. Code C135462.

A score originally developed by Solez et al. (1993), and assigned based on the histologic evaluation of kidney allograft biopsies and the Banff Working Classification from the Banff Foundation for Allograft Pathology. 